\title{
POSSIBLE SASKATCHEWAN SIGHTING OF BLACK VULTURE
}

On 25 May 1992 I saw a black-coloured bird about the size of an Osprey hovering and soaring over the south edge of Qu'Appelle Valley, 1.5 $\mathrm{km}$ west of Fort Qu'Appelle. It soared like a Turkey Vulture, but intermittently it would hover with a great flapping of its wings. I watched it for about a minute at a distance of about $1 / 6 \mathrm{~km}$ ( a quarter of a mile) with $16 x$ binoculars. It was all black underneath and had a prominent white patch on the underside of each wing near the tip. The sun was at right angles to the bird and myself, so I was getting a shaded view of it. The tail differed from that of the Turkey Vulture in that it was short and spread.

I checked my bird guide and found that it resembled the picture of the Black Vulture. When I went to watch the bird again it moved off high into the sky, and off to the west. I then phoned in the report to the Regina bird alert as a "possible" sighting of a Black Vulture. I was still not fully persuaded in my mind as to whether it was a melanistic Osprey or a Black Vulture, for Ospreys will sometimes show fairly prominent white patches near the wing-tips. The next day I drove west along the valley. I did not see the bird again, but I did see several Ospreys. Their manner of flight was so different from the bird I had seen the day before that I was persuaded that it had to be a Black Vulture.

The Black Vulture normally ranges north to the southern tip of Illinois. There are records of stray birds north to southern Ontario, British Columbia and Yukon. Most (if not all) previous reports of Black Vultures in Saskatchewan have proven to be immature Turkey Vultures for the immatures have black heads instead of red. This unconfirmed report only places the Black Vulture on Saskatchewan's list of hypothetical birds.

- RONALD R. HOOPER, Box 757, Fort Qu'Appelle, Saskatchewan. SOG 1 SO

\section{SASKATCHEWAN SIGHTING OF A RED-SHOULDERED HAWK}

On 14 September 1990 I saw a medium-sized hawk on a power pole as I drove north on Highway 35 about $8 \mathrm{~km}$ north of Bankend, Saskatchewan. It had a dark brown back, head and wings. The shoulder was reddish brown, contrasting strongly with the dark brown of the rest of the wing. It was obviously a Red-shouldered Hawk, which is only hypothetical on the Saskatchewan bird list, as it has not been confirmed by a specimen or a photograph. In the Field Checklist of Saskatchewan Birds (1990), Bob Kreba reported four sightings of this species for the province. Unfortunately, I did not have a camera with me to confirm the record.

- RONALD R. HOOPER, Box 757, Fort Qu'Appelle, Saskatchewan. SOG 1 SO 